\title{
Some Histochemical Observations on the Interrenal Glands of Stingray and Bull-head Shark*
}

\author{
Mikio OgURI** \\ (January 24, 1973)
}

\begin{abstract}
Histochemical observations were made on the interrenal glands of the stingray, Dasyatis akajei, and bull-head shark, Heterodontus japonicus. The interrenal glands of the stingray showed high activity of $3 \beta$-hydroxysteroid dehydrogenase, and was abundant in fats and cholesterol. On the contrary, the glands of the bull-head shark showed low activity of the enzyme. The content of fats and cholesterol was also low, compared with that of the stingray. These results seem to indicate differences in corticosteroidogenesis between the two species studied, showing poor production of corticosteroids in the interrenal glands of the bull-head shark.
\end{abstract}

The interrenal glands of Chondrichthyes are known to be abundant in fats, cholesterol and ascorbic acid. ${ }^{1-3)}$ From the studies using mammalian adrenal glands, these substances are said to be concerned with steroidogenesis in the adrenal cortex. In the interrenal glands of Chondrichthyes, however, biochemical studies indicate poor production of corticosteroids., ${ }^{4,5}$ In the biosynthesis of those steroids $3 \beta$-hydroxysteroid dehydrogenase is an important enzyme, because it plays a key part in the conversion from pregnenolone to progesterone in the process. ${ }^{8)}$ The author examined histochemically this enzyme in the chondrichthyean interrenal gland, to get some informations about steroidogenesis in Chondrichthyes. Histochemical observations on fats and cholesterol were also added.

\section{Materials and Methods}

The interrenal glands of Chondrichthyes investigated were obtained from four specimens of stingray, Dasyatis akajei, and seven of bull-head shark, Heterodontus japonicus. These fishes were supplied by a marine fish dealer in Nagoya City. The activity of $3 \beta$-hydroxysteroid dehydrogenase in the interrenal gland was histochemically examined by the method of BARA. ${ }^{7}$ Interrenal glands of these fishes were rapidly frozen with dry ice, and sectioned immediately using cryostat maintained at $-25^{\circ} \mathrm{C}$. Dehydroepiandrosterone (Sigma) and nitro blue tetrazolium (Sigma) were used as hydroxysteroid substrate and final hydrogen acceptor, respectively. For the purpose of comparing, histochemical observations of this enzyme were made also on the adrenal cortex or inter-

* The outline of this report was presented at the annual meeting of the Japanese Society of Scientific Fisheries, Tokyo, Japan, April, 1970.

** Fisheries Laboratory, Faculty of Agriculture, Nagoya University, Nagoya, Japan.（小栗幹郎：名 古屋大学震学部水産学教室) 
renal tissues of the following species of vertebrates: rat, Rattus norvegicus (WISTARIMAMICHI strain), fowl, Gallus gallus domesticus, rainbow trout, Salmo gairdneri and Funa, Carassius auratus.

In addition to examining this enzyme activity, half parts of the interrenal glands of these fishes were fixed in BAKER's formol calcium fluid ${ }^{81}$ and frozen sections were made. Using these sections, fats were stained with $O$ il red $O$ and cholesterol was examined by the SCHULtZ method ${ }^{8)}$. In the fat stain with Oil red O, MAYER's acid hemalum was used as nuclear stain. For the demonstration of cholesterol, modified method of WeBER et al. ${ }^{9 \prime}$ was also employed. But Schultz's original method was much more satisfactory.

\section{Results and Discussion}

The activity of $3 \beta$-hydroxysteroid dehydrogenase was definitely demonstrated in the frozen sections of all the interrenal glands of stingray investigated (Fig. 1). The activity was high and deposition of many bluish violet granules was observed in the interrenal tissue. The intensity of the reaction was similar to that in the sections of adrenal cortex of rat or the interrenal tissues of fowl, rainbow trout and Funa, used for comparison. On the contrary, weak or slightly positive reaction of this enzyme was observed in the interrenal gland of bull-head shark. The granules deposited in the tissue reduced considerably in number (Fig. 2). Table 1 summarizes data obtained from the present observation.

Table. 1. $3 \beta$-hydroxysteroid dehydrogenase activity in the interrenal glands of Chondrichthyes.

\begin{tabular}{|c|c|c|c|c|}
\hline & No. of fish & Sex & Length & Enzyme activity \\
\hline & 1 & $F^{*}$ & $36 \mathrm{~cm}^{* *}$ & $+t+t$ \\
\hline Dasyatis akajei & 2 & $"$ & 37 & $+t+t$ \\
\hline \multirow[t]{4}{*}{ (Akaei) } & 3 & $"$ & 33 & $+t+$ \\
\hline & 4 & $\mathbf{M}$ & 27 & $++t+$ \\
\hline & 1 & $\mathrm{~F}$ & $55 * * *$ & \pm \\
\hline & 2 & ", & 48.5 & + \\
\hline Heterodontus japonicus & 3 & $\mathbf{M}$ & 72 & + \\
\hline \multirow[t]{4}{*}{ (Nekozame) } & 4 & $"$ & 60 & + \\
\hline & 5 & $"$ & 65 & + \\
\hline & 6 & $"$ & 75 & \pm \\
\hline & 7 & $"$, & 64 & \pm \\
\hline
\end{tabular}

* F: Female; $\mathrm{M}$ : Male, ** Until the ene of pelvic fin, *** Total length.

Fats and cholesterol were abundantly detected also in the interrenal gland of stingray. Many fat droplets stained with Oil red 0 were observed in red color (Fig. 3). Treatment of the interrenal sections of stingray with SCHULTZ method induced also intensive reac- 
tion of bluish green colour, indicating the presence of cholesterol. On the contrary, fat droplets detected were not abundant in the interrenal gland of bull-head shark (Fig. 4). Also, Schultz reaction for cholesterol was considerably weak in the tissue of this shark.

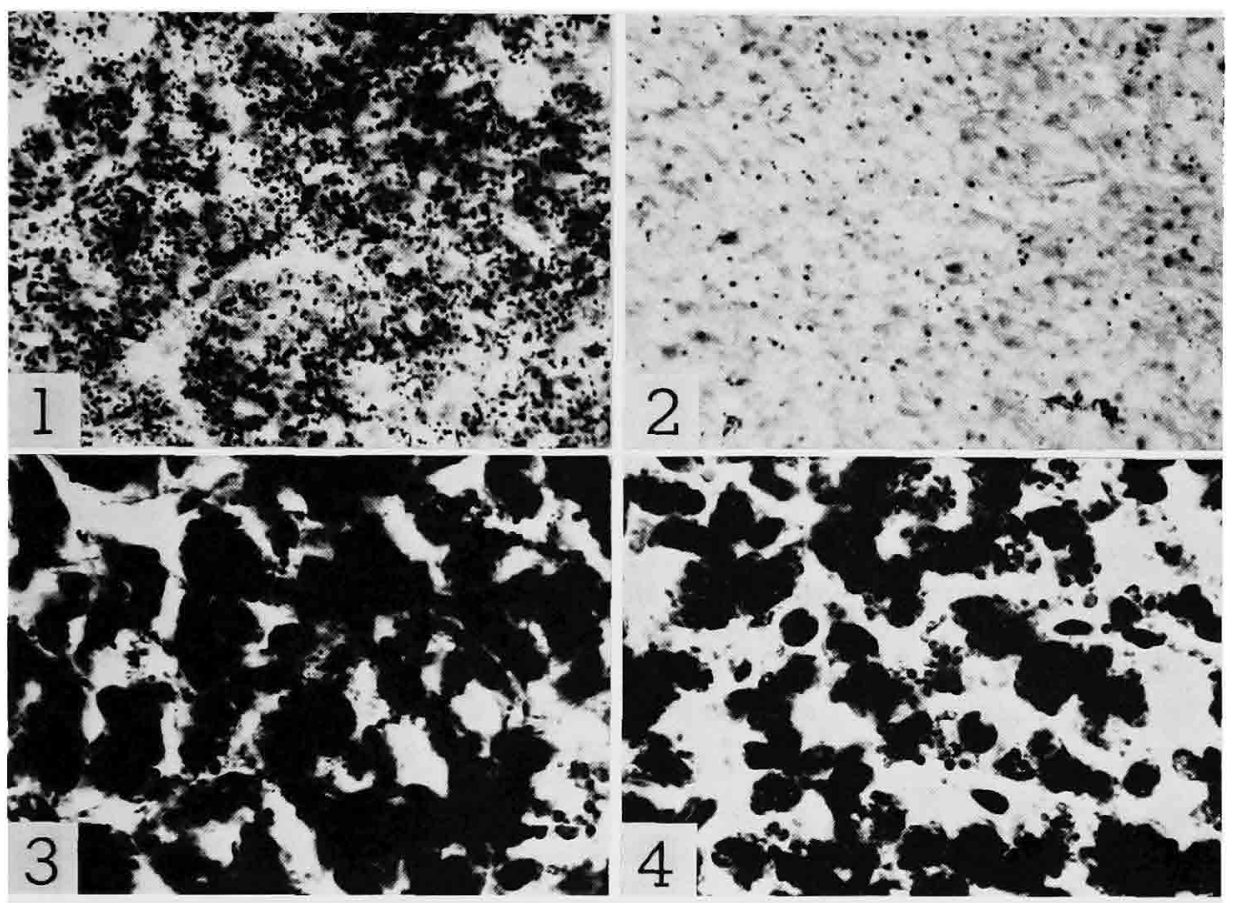

Figs. 1 and 2. Histochemical demonstration of $3 \beta$-hydroxysteroid dehydrogenase in the interrenal glands.

BARA method. Incubation time: 15 minutes, nitro blue tetrazolium, $16 \mu . \times 514$.

Figs. 3 and 4. Fat droplets in the interrenal glands. Fixation by BAKER's formol calcium fluid, Oil red $O$ and MAYER's acid hemalum stain. $\times 514$.

Fig. 1 and 3. Stingray, Dasyatis akajei; Figs. 2 and 4. Bull-head shark, Heterodontus japonicus.

CHIEFFI et al. ${ }^{10)}$ demonstrated histochemically the presence of $3 \beta$-hydroxysteroid dehydrogenase in the interrenal glands of Torpedo marmorata, T. ocellata, Scyliorhinus, stellaris, and $S$. canicula. This result was confirmed by the present observation. However, histochemically, differences in the enzyme activity were detected between the two species of Chondrichthyes used. The activity was much weaker in the interrenal gland of bullhead shark. Also, fats and cholesterol were not abundant in the interrenal gland of this fish, compared with those in that gland of stingray. These histochemical data indicate the difference in the interreal corticosteroidogenic activity between the two chondrichthyean species used in the present observation. With reference to this, BERN et al. ${ }^{4}$ detected biochemically the weak activity of corticosteroidogenesis in the interrenal 
glands of spiny dogfish, Squalus acanthias, and skate, Raja rhina, although they ascertained the production of cortisol, corticosterone and aldosterone in the glands. On the other hand, IDLER and TRUSCOTT ${ }^{111}$ found $1 \alpha$-hydroxycorticosterone as a new corticosteroid in the skate, $R$. radiata. High activity of $3 \beta$-hydroxysteroid dehydrogenase and abundance of fats and cholesterol in the interrenal gland of stingray suggest active biosynthesis of corticosteroids such as $1 \alpha$-hydroxycorticosterone in the gland of this species.

\section{References}

1) H. A. BerN: Science, 158, 455-462 (1967).

2) M. Oguri: This Bull., 26, 448-451 (1960).

3) M. Fontaine and J. Hatey: Bull. Inst. Océanograph., 47, 1-7 (1954).

4) H. A. Bern, C. C. DeRoos and E. G. Biglieri: Gen. Comp. Endocrinol., 2, 490-494 (1962).

5) I. A. MACCHI and F. Rizzo: Proc. Soc. Exp. Biol. Med., 110, 433-436 (1962).

6) J. NANDI: Amer. Zoologist, 7, 115-133 (1967).

7) G. Bara: Gen. Comp. Endocrinol., 5, 284-296 (1965).

8) R. D. Lillie: Histopathologic Technic and Practical Histochemistry, 3rd ed., McGraw-Hill, New York, 1965, pp. 715.

9) A. F. Weber, M. G. Phillips and J. T. Bell, Jr.: J. Histochem. Cytochem., 4, 308-309 (1956).

10) G. Chieffi, V. Botte and T. ViscA: Acta Med. Romana, 1, 108-116 (1963). (Cited from J. NANDI)

11) D. R. Idler and B. Truscott: J. Fish. Res. Bd. Canada, 23, 615-619 (1966). 